\title{
Kształtowanie przedsiębiorczości jako narzędzie uwalniania potencjału gospodarczego społeczeństwa i rozwoju społeczno-gospodarczego
}

DOI: $10.47050 / 65591760.64-78$

Wojciech Piontek

W tekście podjęta została problematyka kształtowania potencjału przedsiębiorczości społeczeństwa. Przedstawiono współczesną teorię rozwoju społeczno-gospodarczego, ze szczególnym wskazaniem roli przedsiębiorcy i przedsiębiorczości w tym procesie. Określony został zakres polityki państwa na rzecz rozwoju przedsiębiorczości. Przedmiotem analizy są zagadnienia kształtowania atrybutów przewagi konkurencyjnej narodu oraz kapitału ludzkiego. Omówione zostały wybrane czynniki stanowiące zagrożenie dla rozwoju przedsiębiorczości i rozwoju społeczno-gospodarczego.

\section{Słowa kluczowe:}

rozwój społeczno-gospodarczy

konkurencyjność

przedsiębiorczość

kształtowanie przedsiębiorczości

kapitał ludzki

atrybuty przewagi konkurencyjnej 


\section{Shaping entrepreneurship as a tool for releasing the economic potential of the society as well as social and economic development}

DOI: $10.47050 / 65591760.64-78$

Wojciech Piontek

This chapter deals with the problem of shaping the entrepreneurial potential in the society. It presents the contemporary theory of the social and economic development, with special emphasis on the role of an entrepreneur and entrepreneurship in this process. The scope of the state policy for the development of entrepreneurship has also been determined. The subject of consideration are the issues related to shaping the attributes competitive advantage of the nation and human capital. Selected factors that pose a threat to the development of entrepreneurship as well as the social and economic development have also been discussed.

Keywords:

social and economic development

competitiveness

entrepreneurship

shaping entrepreneurship

human capital

attributes of competitive advantage 


\section{Wstęp}

W okresie od rewolucji przemysłowej i pojawienia się pojęcia przedsiębiorcy w pracach R. Cantillona, pojęcie to, jak i wskazywana rola przedsiębiorczości, w rozwoju gospodarczym ewoluowały. Pozostawały one ściśle związane z etapem rozwoju gospodarki i akceptowanymi w danym okresie teoriami wzrostu i rozwoju gospodarczego. Poszczególne etapy rozwoju wyznaczane są ewolucją źródeł narodowej przewagi na arenie międzynarodowej oraz typem branż przemysłowych odnoszących sukces. Minionymi etapami rozwoju gospodarek w krajach wysokorozwiniętych były etap rozwoju oparty na czynnikach produkcji (ziemia, praca, kapitał) oraz etap rozwoju oparty na inwestycjach. W obecnym etapie o przewadze decydują innowacje. Kolejnym okresem rozwoju będzie etap oparty na majątku narodowym (Porter 1990). Etap ten jest już sygnalizowany w rodzących się nowych nurtach myśli ekonomicznej, w szczególności ekonomii rozwoju, ekonomii stanu stacjonarnego, czy ekonomii współdzielenia. Należy oczekiwać, że wymusi on redefiniowanie pojęcia przedsiębiorcy i znaczenia przedsiębiorczości dla rozwoju społeczno-gospodarczego.

\section{Przedsiębiorczość w teorii rozwoju społeczno-gospodarczego}

Zagadnienie znaczenia przedsiębiorczości dla rozwoju społeczno-gospodarczego jest silnie zróżnicowane w ramach szkół i nurtów teorii ekonomii. Współczesne rozumienie pojęć rozwoju, przedsiębiorcy oraz rola przedsiębiorczości w stopniu znaczącym zostało zdefiniowane przez J. Schumpetera (1960), a następnie rozwinięte w licznych pracach ekonomistów, jak i koncepcjach polityczno-gospodarczych. Bezpośrednie lub pośrednie odniesienia, nawiązania i rozwinięcia teorii zawarte zostały między innymi w pracach: P. Druckera, I. Kirznera, J.K. Galbraitha, E.D. Domara, P.M. Romera. Autorzy ci akcentują konieczność nieustannej innowacyjności, przedsiębiorczości i nowych strategii działania w szybko zmieniającym się świecie jako warunków koniecznych dla zapewnienia wzrostu i rozwoju społeczno-gospodarczego.

Schumpeterowski rozwój jest procesem obejmującym:

$\rightarrow$ Zmiany w życiu ekonomicznym powstające z własnej inicjatywy, od wewnątrz. Zmiany narzucane z zewnątrz, wynikające $z$ od- 
działywania czynników zewnętrznych, mają charakter wyłącznie dostosowawczy, a rozwój jako taki nie występuje1.

$\rightarrow$ Występowanie zjawisk jakościowo nowych. Rozwojem nie jest proces wzrostu liczby ludności i bogactwa pozbawiony zjawisk jakościowo nowych. Proces taki ma charakter wyłącznie zmiany danych.

$\rightarrow$ Żywiołowość nie posiadającą charakteru ciągłego zmianą drogi ruchu okrężnego oraz zakłócaniem stanu równowagi w gospodarce.

$\rightarrow$ Pięć kategorii procesów - wprowadzanie nowych towarów, wprowadzanie nowych metod (technologii) produkcji, otwieranie nowych rynków, zdobywanie nowych źródeł surowców lub półfabrykatów, przeprowadzenie nowej organizacji jakiegoś przemysłu. (Schumpeter 1960).

W zbudowanych na fundamencie szkoły schumpeterowskiej teoriach i modelach rozwoju/wzrostu endogenicznego eksponuje się wewnętrzne czynniki wzrostu, na które można oddziaływać i kształtować zgodnie z wyznaczonymi celami. Ich wpływ na wzrost i rozwój pozostaje funkcją zainwestowanego kapitału, jak również innych podejmowanych działań. Wśród wskazywanych czynników rozwoju podstawowe znaczenie przypisuje się kapitałowi ludzkiemu. Wysoko wykwalifikowane i przedsiębiorcze społeczeństwa są źródłem innowacyjności, postępu technologicznego i w konsekwencji decydują o wzroście i rozwoju społeczno-gospodarczym. Kreowanie wzrostu gospodarczego wymaga od podmiotów odpowiedzialnych za funkcjonowanie gospodarek nieustannego kształcenia społeczeństwa zgodnie z przyszłymi, prognozowanymi trendami rozwojowymi oraz pobudzania i ukierunkowywania innowacyjności i przedsiębiorczości.

Przedstawiony mechanizm rozwoju nie jest pozbawiony wad. Innowacyjność i postęp technologiczny stwarzają jedynie gospodarce możliwość wzrostu i nie gwarantują, że wzrost zostanie zrealizowany. Innowacyjność odpowiada za immanentną cechę gospodarki wolnorynkowej jaką jest bezrobocie (Domar 1962) Jednocześnie przedsię-

1. Zgodnie z przedstawionym podejściem, działania na rzecz dostosowania polskiej gospodarki, infrastruktury do wymogów definiowanych i narzucanych przez UE i realizowanych już w innych państwach nie jest procesem rozwoju gospodarczego. 
biorcom współczesna ekonomia przypisuje funkcję kreowania nowych potrzeb i popytu na innowacyjne produkty. Bierność przedsiębiorcy w kreowaniu nowych potrzeb i popytu skutkuje brakiem wzrostu i rozwoju gospodarczego.

Schumpeterowski przedsiębiorca jest szczególnym typem człowieka, posiadającym przywilej tworzenia nowych kombinacji środków produkcji i tworzącym nową wiedzę (Schumpeter 1960). Bycie przedsiębiorcą pozostaje ściśle związane z funkcją i działaniami na rzecz tworzenia innowacyjności (Glapiński 2012). Przedsiębiorca zaprzestający działań na rzecz tworzenia innowacji przestaje być przedsiębiorcą i staje się biznesmenem. Cechami charakteryzującymi osobę, które pozwalają stać się przedsiębiorcą, są: zdolność przewodzenia, umiejętność odejścia od utartych ścieżek postępowania oraz odporność na krytyczne reakcje środowiska (Glapiński 2012). W prowadzonej analizie schumpeterowskiej teorii przedsiębiorcy równie ważnymi i ciekawymi są motywy działania przedsiębiorców, w szczególności: „marzenie i chęć stworzenia prywatnego królestwa i zwykle, choć niekoniecznie - również dynastii (...); pragnienie zdobywania: chęć do walki, do okazania swej wyższości nad innymi, do zwyciężania nie dla jego owoców, lecz dla samego zwyciężania. $Z$ tego punktu widzenia działanie ekonomiczne staje się czymś podobnym do sportu (...); radość tworzenia, dokonania czegoś lub po prostu ćwiczenia swej energii i pomysłowości" (Schumpeter 1960, s.148-150).

Potwierdzeniem znaczenia shumpeterowskiego podejścia do zagadnienia rozwoju i teorii przedsiębiorczości jest analiza mechanizmów wzrostu i rozwoju gospodarek wysokorozwiniętych. Stanowi ono także fundament teoretyczny koncepcji rozwoju gospodarczego Unii Europejskiej w XXI w. Przedstawiona przez UE koncepcja gospodarki niskoemisyjnej i oszczędnej w zasoby jest próbą budowy międzynarodowej przewagi konkurencyjnej i wzrostu gospodarczego Europy w oparciu o tworzenie nowej wiedzy $\mathrm{i}$ innowacje $w$ zakresie zmniejszania negatywnego oddziaływania procesów gospodarowania na środowisko przyrodnicze. Słuszne wydaje się zatem twierdzenie, że "nadchodzq̨cy okres stanie się "erq schumpeterowskq̨»" (Mikosik 1960, s. XII). Czynnikami rozwoju gospodarczego będą rządziły precyzyjnie ukierunkowany proces innowacji i kreacja kredytu. W pełni aktualna pozostaje także teza F.A. von Hayeka, że fundamentem dla podejmowanych działań jest akt wiary, iż nauka zapewni konieczny poziom innowacyjności, dyfuzji roz- 
wiązań oraz że zadziała efekt mnożnika. Przedsiębiorca w XXI w. będzie przedsiębiorcą schumpeterowskim nieustannie tworzącym nową wiedzę, a co zatem następuje kształtowanie przedsiębiorczości wymaga kształtowania cech i zmiennych wskazywanych przez J. Schumpetera.

\section{Kształtowanie przedsiębiorczości}

Rozwój gospodarczy, społeczny i kulturowy nie następuje samoczynnie. Jest wynikiem działań państwa tworzącego uwarunkowania rozwoju oraz aktywności przedsiębiorców (Zioło 2015). Wymaga prowadzenia świadomej polityki rozwoju przedsiębiorczości, ukierunkowanej na kształtowanie atrybutów przewagi konkurencyjnej oraz kapitału ludzkiego. Charakter ingerencji państwa w przebieg procesów gospodarczych określił F.A. von Hayek w Konstytucji wolności (2012) wskazując, że fundamentem funkcjonowania gospodarki wolnorynkowej winny być rządy prawa tworzonego w oparciu o prawo naturalne. Prawo stanowione tworzone na gruncie prawa naturalnego ze swej istoty przeciwdziała negatywnym skutkom procesów gospodarczych. "Cała ta działalność państwa ma stwarzać sprzyjające warunki do podejmowania decyzji indywidualnych, dostarczać środków, których jednostki mogą użyć do własnych celów. Do tej samej kategorii należy również wiele innych usług o charakterze bardziej materialnym. Chociaż rządowi nie wolno wykorzystywać swej władzy przymusu w celu rezerwowania dla siebie rodzajów działalności" (Hayek 2012, s. 223). Hayekowski prymat rządów prawa tworzonego w oparciu o prawo naturalne został odrzucony na rzecz "wolności gospodarczej" przez szkołę chicagowską. Fałszywie rozumiana „wolność gospodarcza” może jednak stać się źródłem negatywnych zjawisk i procesów, w tym niszczących przedsiębiorczość.

Celem działań państwa w zakresie rozwoju przedsiębiorczości jest budowanie przewagi konkurencyjnej narodu opisanej przez „teorię przewagi konkurencyjnej narodów" M. Portera. Poszukiwanie czynników konkurencyjności na poziomie krajowym jest błędem. Należy poszukiwać odpowiedzi na pytania co determinuje wydajność oraz tempo jej wzrostu na poziomie poszczególnych branż (działów) przemysłu. Jak wskazuje M. Porter szczegółowa analiza poszczególnych gospodarek pozwala wskazać istotne między nimi różnice, w konsekwencji zaś dokonać identyfikacji cech narodowych przyczyniających się do uzyskania przewagi konkurencyjnej przez przedsiębiorstwa. Cechy te są zarazem czynnikami przewagi konkurencyjnej danego państwa. 
Szczególnie znaczącym i istotnym jest dokonane przez M. Portera (1990) spostrzeżenie, że w skali świata, podmioty gospodarcze posiadające rzeczywistą międzynarodową przewagę konkurencyjną zbudowały ją bazując na cechach jedynie kilku narodów. Źródeł przewagi konkurencyjnej państw Porter upatruje w czterech atrybutach tworzących tzw. diament przewagi konkurencyjnej: czynnik otoczenia, czynnik popytu, obecność w kraju powiązanych i wspierających się branż oraz strategie firm, struktura i rywalizacja. Atrybuty te winny być przedmiotem szczególnej troski zarządzających państwami. Wymagają nieustannego kreowania i podtrzymywania. Atrybuty określają charakter krajowego otoczenia, w którym przedsiębiorstwa powstają i uczą się konkurować. Każdy z atrybutów z osobna, jak i wszystkie jako system kształtują uwarunkowania niezbędne do osiągnięcia przez przedsiębiorstwa międzynarodowej konkurencyjności. Do uwarunkowań tych zaliczyć należy: dostępność zasobów i umiejętności; dostępność informacji rynkowych stwarzających szansę, iż przedsiębiorstwa dostrzegą kierunki, w których należy rozmieścić umiejętności i zasoby; cele właścicieli, menedżerów oraz pracowników w spółkach; presję na przedsiębiorstwa do inwestowania i wdrażania innowacji. Najważniejszym z uwarunkowań decydujących o uzyskiwaniu przez państwo międzynarodowej przewagi konkurencyjnej jest nieustannie wywierana na przedsiębiorstwa presja (Porter 1990).

Równie istotnym, co diament przewagi konkurencyjnej, czynnikiem rozwoju społeczno-gospodarczego jest kapitał ludzki (pośrednio wpisany w atrybuty tworzące diament). Kapitał ten określają system wartości moralnych, cechy osobowościowe, zasób wiedzy użytecznej i nieużytecznej. Proces budowy kapitału obejmuje kształtowanie wskazanych cech, jak również przeciwdziałanie zjawiskom i procesom niekorzystnym i destrukcyjnym. Kształtowanie kapitału ludzkiego jest procesem długotrwałym i szczególnie złożonym.

Wartości moralne determinują przyjmowane postawy, przekonania, a także ukierunkowują życie jednostki, jak i społeczeństwa. System wartości przedsiębiorcy działającego w warunkach gospodarki kapitalistycznej powinien bazować na wskazywanym przez F.A. von Hayeka prawie naturalnym. W swoich działaniach przedsiębiorca powinien pozostawać w zgodzie z „zasadą uświęconą przez czas «nie czyń drugiemu, co tobie niemiłe»" oraz "przynajmniej w miernym stopniu trzymać się podstawowych zasad moralnych" (Anderson 1998, s. 152). Jak wska- 
zuje Sider (1997) odrzucenia wymaga między innymi wszechobecna chciwość, która "stała się główną wadą zachodniej cywilizacji” (Sider, 1977, s.123). Kierowanie się wskazanymi zasadami stanowi warunek konieczny, aby rozwój przedsiębiorczości współistniał z rozwojem społecznym. Przedsiębiorcy odrzucający wskazane wartości, przyczyniają się wyłącznie do rozwoju gospodarczego. Ich działalność nie przyczynia się do rozwoju potencjału społecznego, w skrajnych przypadkach prowadzi do jego zniszczenia.

Wśród wymagających kształtowania przez państwo cech osobowościowych przedsiębiorcy istotne miejsce zajmują odpowiedzialność, zdolności przywódcze oraz wiedza. W literaturze odpowiedzialność przedsiębiorcy definiowana jest jako gotowość lub konieczność ponoszenia konsekwencji pozytywnych i negatywnych efektów wewnętrznych i zewnętrznych podejmowanych decyzji i działań (Piontek 2018). Odpowiedzialność przedsiębiorcy może być odpowiedzialnością naturalną lub zrelatywizowaną. Szczególnie pożądanym jest kształtowanie odpowiedzialności rozumianej w sensie naturalnym, będącej odpowiedzialnością obiektywną i absolutną, pozbawioną relatywizmu. Nie odnosi się ona do obowiązującego w danym momencie systemu normatywnego, a bezpośrednio wynika z prawa naturalnego. Pozostaje niezmienna w czasie. (Kruszyński 2015). Zapewnia przestrzeganie zasady „nie czyń drugiemu, co tobie nie miłe”, a działalność przedsiębiorcy służy dobru ogólnemu. Jej przeciwieństwem jest odpowiedzialność zrelatywizowana, definiowana przez obowiązujący w danym czasie system normatywny. Podlega zmianom w czasie wraz ze zmianami systemu normatywnego, na bazie którego jest formułowana. (Kruszyński 2015). Na płaszczyźnie gospodarczej podporządkowana jest doktrynie nieustającego wzrostu gospodarczego. Pozwala na ocenianie zachowań moralnie nagannych jako odpowiedzialnych oraz ekonomicznie i społecznie pożądanych. Przykładami koncepcji urzeczywistniających zrelatywizowaną odpowiedzialność przedsiębiorcy są koncepcja społecznej odpowiedzialności biznesu oraz koncepcja rozszerzonej odpowiedzialności producenta.

Wskazywanymi przez J. Schumpetera cechami przedsiębiorcy są zdolność przewodzenia, umiejętność odejścia od utartych ścieżek postępowania, odporność na krytyczne reakcje środowiska. Cechy te nie są pożądane w świecie podporządkowanym interesom globalnych korporacji. Ich przedstawiciele deklarując swoje oczekiwania wobec 
procesów kształcenia na uczelniach wyższych, wśród pożądanych cech przyszłych pracowników wskazują: umiejętność pracy w zespole, umiejętność podporządkowania się obowiązującym w organizacji zasadom, czy wąską specjalizację w zakresie kompetencji. Przeprowadzone w Polsce badania w zakresie preferowanych przez pracowników, jak i kadrę managerską systemów zarządzania wykazały, że wartości takie jak samodzielność, autonomia, odpowiedzialność są wartościami wyłącznie środowiska naukowego, które usiłuje je imputować społeczeństwu. Zarówno kadra menadżerska, jak i pracownicy nie dążą do wyzwolenia się z przywództwa i preferują autokratyczny system zarządzania (Haromszeki, Jarco 2014).

Fundamentem zdolności innowacyjnych przedsiębiorcy jest szeroki zakres wiedzy użytecznej i nieużytecznej z różnych dziedzin nauki. Umożliwia on poszukiwanie interdyscyplinarnych powiązań i możliwości rozwoju, a w konsekwencji tworzenie „epokowych innowacji”. Odrzucenia wymaga pogląd nawołujący do eliminacji z programów nauczania treści „niezwiązanych z życiem”, które mają sprawiać, iż kształcenie jest mało atrakcyjne i nie służy wyzwalaniu motywacji i ciekawości intelektualnej (Gęsicki 2004). Wiedza "niezwiązana z życiem” stanowi potencjał tworzenia nowej wiedzy i innowacji. Dziedziny nauki takie jak filozofia, logika, historia kształtują system wartości moralnych, jak i zdolności logicznego myślenia, dedukcji. Podnoszenie wśród społeczeństwa zasobu wiedzy stanowi podstawę, a nie czynnik rozwoju i wzrostu poziomu życia. Warunkiem koniecznym rozwoju jest przekształcanie natury społeczeństwa i wprowadzanie zmian w sposobie wyobrażania przez członków społeczeństwa przyszłego życia zarówno swojego, jak i swoich dzieci. Wizja przyszłości musi być na tyle silna, aby powodować zmiany w zachowaniu (Lucas 2010).

\section{Procesy i zjawiska destrukcyjne}

Dla rozwoju przedsiębiorczości równie istotne jest przeciwdziałanie procesom i zjawiskom niepożądanym i destrukcyjnym. Wśród przykładowych zagrożeń można wskazać destrukcyjną funkcję mediów, internetu i wirtualnej rozrywki oraz obniżanie się poziomu edukacji. $\mathrm{Na}$ problem jakości kształcenia w wyniku traktowania szkoły wyższej jako zwykłego przedsięwzięcia biznesowego i masowości studiów, szczególnie niestacjonarnych, zwracało uwagę wielu autorów, m.in. K. Równy (2008) i A. Boczkowski (2014). W następstwie rozwoju wyższych szkół 
prywatnych na studia przyjmowani byli i są wszyscy bez specjalnych wymogów w zakresie poziomu wiedzy, gdyż bardzo często jedynym kryterium przyjęcia na studia jest posiadanie matury. Z upływem czasu problem ten zaczął dotykać także niektóre uczelnie państwowe, przyjmujące każdego chętnego absolwenta szkoły średniej na mniej popularne kierunki w warunkach niżu demograficznego. Na problem ten zwróciła uwagę także Najwyższa Izba Kontroli w 2018 r., która w raporcie z kontroli za lata 2015-2017 wskazała, że jednym z poważnych problemów jakości kształcenia w szkołach wyższych są niewystarczające wymogi selekcyjne wobec kandydatów na studia (NIK 2018).

Kolejnym problemem edukacji na poziomie wyższym jest tendencja do upraktyczniania kształcenia. Zalążkiem tego procesu był funkcjonujący w minionych dziesięcioleciach pogląd, że wiedza teoretyczna ma znaczenie wtórne wobec praktyki. Podkreślenia wymaga, że zadaniem szkół wyższych jest wyposażenie studenta w jak najszerszy zasób wiedzy ze studiowanej dziedziny, przedstawienie kierunków rozwoju dziedziny, a także kształtowanie umiejętności analitycznych i twórczych. Proces edukacji akademickiej nie może więc być przesadnie ukierunkowany na przygotowanie studenta pod potrzeby przyszłego pracodawcy. Działanie takie może skutkować przekształcaniem szkół wyższych w szkolnictwo zawodowe. Umiejętność pracy w zespole, czy obsługi programów księgowych, magazynowych i liczne pozostałe umiejętności praktyczne ułatwiają funkcjonowanie studenta na rynku pracy najemnej i są być może chętnie widziane przez pracodawców. Przy takim nieprzemyślanym podejściu do kształcenia na poziomie wyższym w celu przygotowania do konkretnej pracy najemnej, trudno jednak kształtować postawy przedsiębiorcze, w tym kreatywność oraz przygotowywać studentów do założenia i prowadzenia własnego biznesu, szczególnie innowacyjnego. Koncentracja procesu edukacji na nabywaniu przez studentów umiejętności praktycznych wpływa negatywnie na potencjał rozwojowy społeczeństwa i zdolność tworzenia nowej wiedzy. Tym samym utrudnia bycie przedsiębiorcą.

Istotnym czynnikiem obniżania narodowego potencjału przedsiębiorczości i innowacyjności są media, internet i wirtualna rozrywka. Wywołują one wskazywane przez M. Spitzera (2015) zjawisko „cyfrowej demencji". Negatywnie wpływają na kształtowanie się neuronalnej sieci mózgu. Wyniszczają zdolności koncentracji i kontemplacji. W sposób istotny zaburzają mechanizm uczenia się, zapamiętywania, uwagi 
i rozwoju. Dzieje się tak wtedy, gdy Internet nie jest traktowany przez jego użytkowników jako narzędzie do pozyskiwania źródeł wiedzy (np. przeszukiwania baz bibliotecznych i pozyskiwania artykułów), a sam w sobie jest źródłem wiedzy. Niestety powszechne stało się bezrefleksyjne korzystanie z informacji przygotowanych przez innych. Zastępuje ono poszukiwanie i zgłębianie źródeł wiedzy, rozważne i krytyczne spojrzenie na zdobyte informacje, weryfikację wiarygodności oraz zdolność wnioskowania (Spitzer 2015).

Wyniki analiz M. Spitzera znajdują potwierdzenie w analizie kompetencji i postaw młodzieży szkół podstawowych, średnich oraz studentów uczelni wyższych. Nieliczni posiadają zdolność do refleksji nad zadanym do przeczytania tekstem, czy oglądanym filmem. Narasta wśród młodzieży (a także społeczeństwa jako całości) problem ze zrozumieniem czytanego tekstu, wynikający jak wskazują naukowcy z braku umiejętności koncentracji oraz zainteresowania tekstem pisanym (Dzierżanowska, Szkolnictwo.pl 2018). Doświadczenie wielu nauczycieli akademickich wskazuje, że część studentów przygotowanie prac semestralnych, zaliczeniowych, licencjackich oraz magisterskich próbuje sprowadzić do kopiowania tekstu z pierwszych wyświetlanych przez przeglądarkę internetową źródeł czy przepisywania książek, a następnie modyfikacji skopiowanego tekstu zgodnie z parametrami działania wykorzystywanego przez szkołę programu antyplagiatowego. Stąd stworzenie Jednolitego Systemu Antyplagiatowego (zob. jsa.opi.org.pl) dla polskich szkół wyższych, powszechny obowiązek korzystania z niego przez uczelnie oraz wysiłek twórców tego typu systemów, aby przeciwdziałać praktykom oszukiwania systemu w celu niewykrycia plagiatu. Na powszechny problem plagiatowania wśród studentów zwracało uwagę wielu autorów, m.in. S. Wawak i K. Woźniak (2005), S. Kawczyński (2007), N. Miranowicz (2011) i M. Łozińska (2018). W takich warunkach, niewątpliwie kończący edukację mogą być biznesmenami prowadzącymi z sukcesami działalność gospodarczą. Niestety w ograniczonym zakresie posiadają kompetencje do bycia przedsiębiorcami w shumpeterowskim znaczeniu.

\section{Podsumowanie i wnioski}

Rola przedsiębiorczości w rozwoju społeczno-gospodarczym w przyszłości będzie nieustannie wzrastała. Rozwój przedsiębiorczości wymaga aktywnego uczestnictwa państwa, wyrażającego prowadzeniem 
polityki rozwoju przedsiębiorczości, kształtowaniem narodowych cech przewagi konkurencyjnej oraz kapitału ludzkiego. W procesie kształtowania kapitału ludzkiego istotnym jest wyraźne rozróżnianie pomiędzy nowocześnie rozumianym przedsiębiorcą, a tradycyjnie pojmowanym biznesmenem, ukierunkowanym tylko na maksymalizację zysków. Przedsiębiorca tworzy nową wiedzę, poszukuje nowych kombinacji środków produkcji. Proces edukacji powinien być ukierunkowany na kształtowanie specyficznych cech charakteryzujących przedsiębiorcę. Równie istotnym jest podejmowanie działań przeciwdziałających procesom i zjawiskom negatywnie wpływającym na potencjał przedsiębiorczości społeczeństwa i hamujących jego rozwój. 


\section{Bibliografia}

$\rightarrow$ Anderson, B. (1998), Zalety wolnej gospodarki [w:] M.W. Hendrickson (red.) Moralność kapitalizmu, Lublin: TheFreeman, Instytut Liberalno-Konserwatywny.

$\rightarrow$ Boczkowski A. (2014), Uniwersytet a kształcenie masowe. Od idei uniwersytetu do ideologii kształcenia na poziomie wyższym [w:] „Przegląd Socjologiczny”, nr 63 (LXIII) / 3, s. 9-37.

$\rightarrow$ Domar, E.D. (1962), Szkice z teorii wzrostu gospodarczego, Warszawa: PWN.

$\rightarrow$ Gęsicki, J. (2004), Przemiany w edukacji [w:] Wymiary życia społecznego, Warszawa: Wyd. Naukowe SCHOLAR.

$\rightarrow$ Glapiński, A. (2012), Schumpeterowska teoria przedsiębiorcy, czyli skąd się bierze pies [w:] „Konsumpcja i Rozwój” nr 1/2012 (2), s. 3-12.

$\rightarrow$ Haromszeki, Ł., Jarco, P. (2014), System wartości menedżerów i pracowników niższego szczebla w świetle badań porównawczych [w:] „Społeczeństwo i Ekonomia" 2(2), s. 34-50.

$\rightarrow$ Hayek, F.A. (2012). Konstytucja wolności, Warszawa: Wyd. Naukowe PWN.

$\rightarrow$ Kawczyński, S. (2007), Problem plagiatowania w szkolnictwie wyższym. Charakterystyka elektronicznego systemu antyplagiatowego [w:] „e-mentor", $\mathrm{nr} 2$, s. 57-62.

$\rightarrow$ Kruszyński, R.J. (2015), Odpowiedzialność naturalna człowieka [w:] Acta Universitatis Lodziensis. Folia luridica, nr 74/2015, Część I - Odpowiedzialność - uwarunkowania etyczne, moralne i prawne.

$\rightarrow$ Lucas, Jr. R.E. (2010), Wykłady z teorii wzrostu gospodarczego, Academia Oeconomica, Warszawa: Wyd. C.H. Beck.

$\rightarrow$ Łozińska, M. (2018), Zjawisko plagiaryzmu w środowisku akademickim [w:] Zeszyty Naukowe Państwowej Wyższej Szkoły Zawodowej w Legnicy, nr 28, s. 189-199.

$\rightarrow$ Mikosik, S., (1960), Przedmowa do wydania polskiego [w:] J.A. Schumpeter, Teoria rozwoju gospodarczego, Warszawa: PWN. 
$\rightarrow$ Miranowicz, N. (2011), Plagiatorstwo - propozycja diagnozy i terapii na podstawie wyników badania ankietowego wśród studentów [w:] „e-mentor", nr 5, s. 26-31.

$\rightarrow$ Piontek, W. (2018), Implementacja rozszerzonej odpowiedzialności producenta do systemu gospodarowania odpadami w Polsce [w:] „Rocznik Ochrona Środowiska", nr 20. s. 1597-1624.

$\rightarrow$ Porter, M.E. (1990), The Competitive Advantage of Nations, Harvard Business Review, March - April.

$\rightarrow$ Schumpeter, J.A. (1960), Teoria rozwoju gospodarczego, Warszawa: PWN.

$\rightarrow$ Sider, R.J. (1977), Rich Christians in an Age of Hunger, Downers Grove: Inter - Varsity Press.

$\rightarrow$ Spitzer, M. (2015), Cyfrowa demencja. W jaki sposób pozbawiamy rozumu siebie i swoje dzieci, Słupsk: Wyd. Dobra Literatura.

$\rightarrow$ Wawak, S., Woźniak, K. (2005), Skuteczny system automatycznego wykrywania plagiatów na przykładzie prac zaliczeniowych studentów Akademii Ekonomicznej w Krakowie [w:] „e-mentor", nr 5, s. 5-9.

$\rightarrow$ Zioło, Z. (2015), Przedsiębiorczość jako czynnik rozwoju społeczno-gospodarczego układów przestrzennych [w:] „Przedsiębiorczość - Edukacja”, 11, s. 8-23. 


\section{Netografia}

$\rightarrow$ Dzierżanowska T., Czytanie ze zrozumieniem - opis i analiza problemu, szkolnictwo.pl/index.php?id=PU0718 (dostęp: 30.11.2018).

$\rightarrow$ NIK (2018), System oceny jakości kształcenia w szkołach wyższych, Najwyższa Izba Kontroli, Warszawa, maj 2018 r., www.nik.gov.pl/plik/id,18018,vp,20610.pdf, www.nik.gov.pl/plik/id,18017,vp,20609.pdf (dostęp: 26.02.2019).

$\rightarrow$ Równy, K, (2008), Konieczność poprawy jakości prywatnego szkolnictwa wyższego w Polsce, "Nauka”, nr 4/2008, s. 101-120, www.pan.poznan.pl/nauki/N_408_07_Rowny.pdf (dostęp: 26.02.2019). 